\title{
INTERVIEWS IN CROSS-CULTURAL RESEARCH: WORKING WITH THE CUSTODIANS OF TRADITIONAL HEALTH PRACTICE AS RESEARCHERS IN SOUTH AFRICA
}

\section{Ramodungoane TABANE ${ }^{1}$}

\begin{abstract}
Traditional health practice (THP) represents one of the lesser-researched and lesser-understood fields, although one that has been practised for centuries. Conducting research in this field requires the research community to devise innovative ways of studying and learning from it. A qualitative research methodology was employed to gain access in the THP field. The study was conducted at three sites in Gauteng and two sites in KwaZulu-Natal in South Africa. In-depth individual interviews were facilitated in local languages by traditional health practitioners who were trained as interviewers. As a result, authentic data were gathered and analysed. The results of the study indicate that emic knowledge, understanding and interpretations can be elicited with appropriate research methodology, especially when the custodians of traditional and cultural practices are included as part of the research team.
\end{abstract}

Keywords: Interviewing; Cross-Culture; Qualitative Technique; Traditional Health Practitioner; Emic Knowledge; Etic Knowledge

${ }^{1}$ Dr., University of South Africa, Department of Psychology of Education 


\section{GÜNEY AFRİKA'DA ARAŞTIRMACI OLARAK GELENEKSEL SAĞLIK PRATİĞİ KORUYUCULARIYLA ÇALIŞMA: KÜLTÜRLERARASI ARAŞTIRMADA GÖRÜŞMELER}

\section{ÖZET}

Yüzyıllardır uygulanmasına rağmen, geleneksel tıp uygulamaları (GTU) az araştırılan ve az anlaşılan alanlardan biridir. Bu alanda araştırma yapmak, araştırmacıların bu alanı çalışması ve öğrenmesi için yenilikçi yöntemler geliştirmesini gerektirir. GTU'na ulaşmak için nitel araştırma yöntemi kullanılmıştır. Bu araştırma Güney Afrika'da, Gauteng'deki üç ve KwaZulu-Natal'daki iki yerleşim yerinde yürütülmüştür. Görüşmeci olarak eğitilen geleneksel tıp uygulamacıları, yerel dillerde bireysel görüşmeleri yürütmüştür. Sonuç olarak özgün ve güvenilir veriler toplanmış ve analiz edilmiştir. Araştırmanın sonuçları emik bilgi, anlayış ve yorumlamaların uygun bir araştırma yöntemiyle, özellikle geleneksel ve kültürel uygulamaların vasileri araştırma grubunun bir parçası olduklarında, açığa ç1karılabileceğini gösterir.

Anahtar Kelimeler: Görüşme; Kültürlerarası, Nitel Teknik, Geleneksel Tıp Uygulamacıları, Emik Bilgi, Etik Bilgi 


\section{INTRODUCTION}

This paper focuses on the research methodology and, specifically, the qualitative research technique employed in the study entitled 'An exploratory study of how Traditional Health Practices (THP) in South Africa communicate the concepts of disease risk and prevention to their patients' (BRHC, Tabane, Mbele-Khama \& Dlamini, 2012). The focus of this paper is the use of interviews as a qualitative research technique or tool in a cross-cultural study; therefore, it is not a presentation of the findings of the aforementioned study. As a cross-cultural study, it purposefully deliberates on the importance of including the custodians of THP as members of the research team and explains how this inclusion was effected.

Numerous qualitative research techniques are employed to generate and collect data. These qualitative research techniques or tools include - but are not limited to - focus groups, interviews, observation and case studies. Qualitative research methodology as an inquiry builds on the presentation of the entire picture of the phenomenon of study and seeks to understand the kilts knitted as the story is narrated by the researcher. It is thus important that the explanations given are a true reflection of the data generated from the participants lived experiences. Thus process of data collected should be equally securitised so that data analysed reflects the participants' stories and not only the researcher's interpretation.

Undertaking a cross-cultural research demands the researchers to "treat people from different cultural backgrounds considerately and with equality" (Chang, 2007: 187). It is thus important that researchers when approaching their studies and/ or project are aware of their competencies in relation to the phenomenon of study, engagements with the participants and the research context. Various authors wrote on cultural competence and according to Chang (2007) literature narrow them to "integrative" and "transformative". The former, demonstrated the complex feature of cultural competency where there is an interrelatedness of concepts like consciousness; knowledge and skill proficiency. While transformative cultural competency is seen as the ability to transform "knowledge, practices, polices and attitudes in appropriate cultural settings to increase the quality of service" (Chang, 2007: 189). This 
paper strived to indicate the transformative cultural competency that interviewers have in influencing research conducted.

The aforementioned study, 'An exploratory study of how Traditional Health Practices (THP) in South Africa communicate the concepts of disease risk and prevention to their patients' (BRHC, Tabane, Mbele-Khama \& Dlamini, 2012), employed two research techniques to generate data, namely focus groups and interviews. In this paper, however, the focus is only on the interviews conducted with the THPs.

Interviews are one of the most popular techniques and tools used in qualitative research methodology to generate and collect research data (Al-Yateem, 2012; Anyan, 2013; Gubrium \& Holstein, 2003; Kvale \& Brinkmann, 2008; Rubin \& Rubin, 2006; Seidman, 2006). This might be so because 'one commonly held assumption, is that interviewing serves as an essential doorway to the interviewee's "authentic" self and that skilled interviewers can have better access to the interviewee's inner truth' (Mori, 2012: 491). However, qualitative research interviews attempt to go beyond descriptions to provide researchers with an in-depth understanding of a phenomenon (Anyan, 2013).

Different types of interviews are used in qualitative research, as they serve a particular purpose. According to Doody and Noonan (2013: 28), 'to conduct a successful interview, researchers need to develop their interview technique, choose the right method and carefully plan for all aspects of the process'.

In cross-cultural research and studies, care must be taken to ensure that the selection of the type of interview does not exclude participants - not only regarding content, but also, for example, regarding other aspects such as language and the level at which the questions are pitched. The power relationship that exists in the interview situation should be closely monitored because in cross-cultural research, the dynamics of power come to the fore. Thus researchers ought to be considerate of their possible limitations in conducting cross-cultural research, psychology assessments, and so forth. They should be 
cognisant of their limitations and continually seek the means to improve their data-generation techniques.

Anyan (2013) refers to the qualitative research interview in terms of power and the relationship between interviewee and interviewer. The interviewer has more power as a researcher, while the interviewee has less power as a respondent. However, the opposite is also true because the respondent or interviewee wields power by holding the information that the researcher seeks, thus leaving the researcher with less power. This power play goes back and forth in what Brinkman and Kvale (2005) in Anyan (2013) call the asymmetrical power relation of the interview. This relationship is delicate and should therefore be treated with respect and sensitivity. The THPs do not readily share their knowledge with outsiders or those that are not part of the THP community. Therefore, the power that the THPs hold can be used to deny or even withhold the information that the researcher seeks. Consequently, the researchers in this study devised a plan to train and make use of the services of THPs as interviewers, thereby minimising the inside-outside dualistic nature of power relations in cross-cultural studies.

Structured and unstructured (open-ended and semi-structured) interviews are employed in research to elicit data on the phenomenon being studied, as required by the researcher. Open and semi-structured interviews are usually used in the qualitative research method. In this study, semi-structured interviews were used.

Rabionet (2011: 563) explains that

qualitative interviewing is a flexible and powerful tool to capture the voices and the ways people make meaning of their experience.... conducting semi-structured interviews requires the following six stages: (a) selecting the type of interview; (b) establishing ethical guidelines; (c) crafting the interview protocol; (d) conducting and recording the interview; (e) analyzing and summarizing the interview and (f) reporting the findings. 
Semi-structured interviews are preferred in qualitative research because they allow the participants to respond by expressing themselves openly or engaging in a narrative about the posed question; this also affords them an opportunity to voice their personal views. The open questions should be combined with more focused questions that will assist in eliciting appropriate answers and giving the interviewees an opportunity to introduce new content. This will also prevent the interviewers from obscuring data during the interview for various reasons, for example through the interviewer's insensitivity, personal views, personal bias and lack of understanding of the nuances surrounding the culture of the phenomenon under study in relation to the participants. Expert interviewers, according to Bogner, Littig and Menz (2009), focus not so much on the personalities of the interviewees as on the need to retrieve their expertise in a specific area. However, the opposite is also true: expert interviewers avoid drawing attention to their personality, but rather focus on how to make the interviewees or participants feel at ease with them so that they will communicate freely.

In a cross-cultural study, it is important to decide not only on the type of interview to use, but also the reasons for conducting the interviews. The type of interview selected should take into consideration the personalities of both the participants/interviewees and the researchers/interviewers. Depending on the phenomena being studied and the nature of the open and semi-structured interviews, the personal views and biases of the participants and the researchers might filter through and thus affect the creation of knowledge. This point is critical in cross-cultural research because personal attributes of both researcher and participants have a bearing on the quality and authenticity of the data generated and, ultimately, on the research that is reported. Frels and Onwuegbuzie emphasise this as follows:

Indeed, the story of the research relationships, both between participant and researcher and between the researcher and his or her data collection process is influential in coloring and contextualizing the written account of the research story (2012: 1).

Alvesson and Sköldberg (2009) point to the complexity of the research interview dynamics and emphasise the importance of being reflective in the interview situation. This is paramount in cross- 
cultural research because, according to these authors reflexivity in research is a 'complex relationship between [the] process of knowledge production and the various contexts of such processes, as well as the involvement of the knowledge producer' (Alvesson \& Sköldberg, 2009: 8).

Numerous research studies (Mutua \& Swadener, 2004; Wilson, 2004, 2008; Webster \& John, 2010) deal with cross-cultural research and the researchers' interaction with the participants in general, but more importantly, with the indigenous people and the implications of these interactions for the research findings. Indeed, the choice of research technique might have implications for the authenticity of the data generated, collected and analysed, the conclusions drawn and, ultimately, the study as a whole. The researcher's reflexivity thus becomes paramount, because an oversight might have dire consequences for the research. Therefore, Chenail (2011: 261) concludes that such a point of view 'can prove to be invaluable in conducting research that is sensitive to...other [cultures different from the researcher's] ... and can lead to more ethical and responsible research'.

Culture, as a research variable, is a fluid concept that is defined in different ways and is linked, in some cases, to aspects such as race, ethnicity, language and subcultures within a particular community. Triandis (2000) in Ǽgisdóttir, Gerstein and Çinarbaş (2008) introduces three approaches of paramount importance when conducting cross-cultural research, namely the indigenous, cultural and cross-cultural approaches. The indigenous and cultural approaches refer to the emics or "uniqueness" of a culture, while the cross-cultural approach focuses on the etics or factors common across cultures. Therefore, when conducting cross-cultural research, the researcher must understand these two concepts and the role that his or her own attributes play in the composition of the cultural setting of the research site, the effect it has on data generation and, ultimately, how these aspects affect the findings of the study. The understanding of the emic knowledge in research as a whole contributes to the richness of the data as it contributes to the body of knowledge the uniqueness that is at times lost in the translation by the researchers. 
Cross-culture in this study was defined by the interaction between the researchers and the THPs. This is important because in qualitative research both the researcher and the respondent are participants. This is so because in qualitative research, the researcher is involved even when applying non-participatory observation, because his or her presence in a research field is by virtue of the fact, deemed to be participation. Thus the use of interviews in cross-cultural research is highlighted and the researcher needs to be reflexive regarding his or her role in that space. Frels and Onwuegbuzie (2012: 1-2) summarise Hesse-Biber and Leavy (2007) on the importance of reflexivity, which is needed when conducting all research, but is imperative when conducting cross-cultural research:

Reflexivity is the process through which a researcher recognizes, examines, and understands how his or her social background and assumptions can intervene in the research process.... Reflexivity goes to the heart of an in-depth interview; it is a process whereby the researcher is sensitive to the important 'situational' dynamics that exist between the researcher and the researched that can affect the creation of knowledge (Biber \& Leavy, 2007: 129-130).

Therefore, conducting interviews in a cross-cultural setting is a science and an art that requires researchers to be aware of their status as, among other things, temporary sojourners - rather than permanent members - of the community concerned, in terms of cultural practices, for instance, even though they might all be of the same race and/or culture.

Al-Yateem (2012) emphasises that in an interview, three factors are at play. This is true in the crosscultural situation as well. According to Al-Yateem (2012), factors that affect interviews are the following:

- Interviewers. Their experience, gender, age and race may all be relevant factors. 
- Participants. They may deliberately try to please interviewers or, alternatively, attempt to prevent them from learning something about themselves; they can do this in the way that they respond, or by omitting particular information.

- Question format. The questions used in the interview, such as leading questions, can affect the responses and impede communication.

It is furthermore, important to note that in social research the aspect of power is important as it affects the data generation and finally collected. According to the feminism and postmodernism perspective both the explicit and implicit power in research should be carefully monitored and reflected in such studies where the participants might feel uncomfortable or through internal suppression feel obliged to participate. According to Kitzinger (1991) it is important to address the concept of power and clarify the meaning we intend by it. In research, especially interviews an impression, founded or not, might create an intended power play where the participants might feel obliged to respond to questions despite being assured that they can pull out of the interview as and when they wish. Thus the researcher must be able to reflect during the research process.

The research reported on in this paper examined the impact that good research practice might have on the manner in which cross-cultural research is conducted. It focuses on the research conducted with THPs as the custodians of the indigenous knowledge system and future research partners or collaborators.

Researchers focusing on the THP field encounter many challenges, as THPs are cautious about divulging information about their practices and do not easily allow outsiders to enter this space and access the emic knowledge and beliefs within their practice.

\section{RESEARCH METHODOLOGY EMPLOYED IN THE STUDY}

In this study, a qualitative research methodology was employed to gain insight into the guarded practice of THP. Different qualitative research designed can be devised from ethnographic study, a

SAD / JSR
Cilt / Volume 19 Sayı / Number 2


phenomenological study, or a narrative study. This was a phenomenological study as it sought to uncover the meaning and essence of given phenomena of study.

The THP interviewers conducted individual in-depth interviews (IDI) with the participants.

\section{SAMPLE OF THE RESEARCH POPULATION}

The participants in the study were THPs from four selected sites (municipalities) in the two identified provinces, namely Gauteng and KwaZulu-Natal. There are THP committees within municipalities that are organised as forums, and each forum keeps a database of practising THPs within their sub-districts. To ensure that the research team did not influence the selection of participants, a letter of invitation was sent to the chairperson and secretary of each THP forum to select the 10 THP participants that met the criteria for this study. Five patients from each site treated by the THPs were invited to participate in the study.

Two types of participants were purposively selected to participate in the focus groups for this study and, later, in the in-depth individual interviews. The first type was the THPs and the second type was the patients being treated by those THPs. However, the focus of this article is on the THPs only. For the selection of the THPs, firstly the Traditional Health Practitioners Act 22 of 2007 was used to identify the types of THPs to participate in the study. This Act recognises four categories of THPs, namely diviners, herbalists, traditional birth attendants and traditional surgeons. Secondly, the THPs' experience was taken into consideration: the sample had to comprise THPs, who had finished their apprenticeship recently (i.e. within the last two years) and those that have been practising for more than two years. Thirdly, the sample also had to include THP trainers or tutors. Lastly, representivity in terms of age (over 18 years) and gender was also considered. At the end of the selection process, there were 40 THP participants, from which 20 were invited to participate in individual in-depth interviews.

\section{RESEARCH TEAM}


The research team in this study comprised one black male, the principal investigator; one white female, the project leader/researcher; one Indian female, the project administrator/researcher (none of whom were THPs, therefore they are referred to as non-THPs in this study); and two senior THP members (one female and one male), who were researchers and regarded as THP experts on the project. The THP experts played a critical role and therefore had to be individuals who were respected in the field of THP, as well as meeting the criteria agreed on by the research team. Firstly, the THP experts had to fall within one or more recognised categories, as prescribed by the Traditional Health Practitioners Act 22 of 2007. Secondly, in terms of their THP experience, the THP experts had to have been training THPs for 10 years and have successfully graduated new THP entrants. THP experts also played a pivotal role in the recruitment and identification of the THP interviewers and assisted in the conceptualisation of the qualitative research methodology and the designing of the research tool, as well as the individual interview protocol. Their input was crucial, as it highlighted equivalence, bias and translations (Ǽgisdóttir et al, 2008) as cross-cultural methodological and design concerns. Most importantly, THP experts supervised the THP interviewers and also coached and mentored the non-THP team members on what was deemed to be acceptable in and around the traditional practices so as they might not act in any manner that might be deemed as offensive, disrespectful or insensitive during the entire study.

\section{SELECTION AND RECRUITMENT OF THE THPS AS INTERVIEWERS}

Collaboration with the THPs and the idea of using them as interviewers was proposed because THPs do not readily interact with people who do not practise THP. Furthermore, "outsiders" who collaborate with the indigenous people or custodians of THP knowledge are generally not trusted; in instances where they are granted access, limitations are imposed on such access. According to Webster and John (2010: 175), 'even those Indigenous communities that allow entry into the field often approach these research “collaborations" with distrust or apprehension'.

The decision to use THP interviewers was also intended to create a research atmosphere where both the participant and the interviewer understood intricate concepts related to the THP practice and in that way 
minimising the inside-outside research situation where either comes from a vantage or disadvantage point. However, one should be mindful that power relations in the interview situation can also surface through personalities, content and manner of the questions are posed. Thus constant reflection by the researcher is critical as a methodological consideration when conducting research.

Given the nature of the THP field and the desire of THPs to protect their space, it was important that the THP interviewers be people who are regarded as having an intimate understanding of the emics of the practice. The interviewers had to be seen to mirror (reflect) the participants and thus possibly reduce the loss of meaning during the interviews that results from language ambiguities and the explanation of concepts, for instance, which could water down the authentic meaning of the intended message. The recruited THP interviewers had to be willing to be trained as interviewers. Furthermore, they had to have been in practice as THPs for some years - and even have started training and tutoring new THP entrants. They also had to be over 18 years of age and in possession of a matriculation certificate. Finally, these trainee interviewers had to be computer-literate, as they would be trained to transcribe the data generated during the interviews.

\section{THE INDIVIDUAL IN-DEPTH INTERVIEWS (IDIS)}

From among the focus groups, five participants from each of the four sites were invited to participate in the individual in-depth interviews (IDIs). The participants were purposefully selected to ensure representivity of the THP categories and to meet the other criteria of the study. Thus the IDIs had to include at least three categories of the THPs recognised in the Traditional Health Practitioners Act 22 of 2007 (with the participation of diviners and herbalists being compulsory). In addition, a traditional tutor had to be present and both genders had to be represented.

\section{FINDINGS}

Conducting cross-cultural research and studies requires the researcher to be aware of the cultural issues that might influence the study negatively. Although it is not possible to achieve a totally bias-free 
research setting in terms of culture, the researchers are required to take cognisance of ethical research considerations in their studies.

In this study, the THPs were recruited to be part of the research team and also to conduct the interviews. Practices like THP have been an interest of research for decades however researchers have been reservedly welcomed in this space. The recruitment and employment of the THPs as interviewers was to create a comfortable environment for the participants to relay with person who understood their customs with the aim of having participants who shared easily.

A participant remarked

"It was easy to speak to a THP unlike a researcher who is interested in stealing our THP ideas" The methodology employed in this study ensured that the emic wealth was shared with the researchers as evidenced by the expression from participants sharing with the THP-interviewers, "But it is easy to talk to you because you also do it and understand me" One other participant remarked to the THP interviewer "Remember this information is our legacy, it was left to for us by the ancestors, right?".

The element of power play was also taken into consideration. According to Anyan (2013), the countermeasures of the knowledge holder and the researcher should be monitored because the researcher is usually an outsider in cross-cultural studies. Thus this study addressed the element of the 'other' searching for information from 'us' about 'our' practices. In this study, all the people involved in the IDIs were engaged with their data and knowledge creation. A participant indicated that "They [researchers] always want things from us but they do not want to share their profits once they make money from the research". This is a clear indication of the lack of trust and always approaching research settings with suspicion. Thus "they want something from us and we chase them away, we do not trust them". 
The use of THP interviewers was also aimed at minimising emic-etic influence in terms of language, misunderstanding of the terms and loss of meaning during the IDI and, ultimately, during analysis and research reporting, which would undermine the study's authenticity.

Non-THP practitioners and researchers run the risk of failing to note subtle messages during data generation. For example, a non-THP interviewer might not discern nuances that explain a rich concept; and even if he/she is of the same race and language as the interviewee, if he/she is not a THP, the meaning of the message might be watered down in translation, thus affecting the original authentic meaning that would have been understood if the interviewer had been a THP. Therefore, by using THP interviewers, the researchers are able to capture this complex knowledge of the emics of the phenomenon being studied. As directly observed during the data collection, participants used THP language, nuances, gestures and so forth that are THP contextualised that non THP researchers were more likely to missing as data cues. For instance, during the interviews THPs would sneeze, use a snuff etc. when taking about certain topic and the THP-interviewers would acknowledge these moments by saying something in traditional language or gesture ("clap hands" or say "Thokoza" [be happy] - an expression to indicate it is safe you can continue for instance). These are the cues that non-THP interviewers would have missed and thus render interview situation as uncomfortable especially interviewees who might feel offended.

The THP interviewers were also tasked with the transcription of the interviews. During the interviews, they had made their own notes, which enriched their data. Furthermore, they recorded the interviews themselves and were thus better placed to recall most of the occurrences and to register the participants' emotions. This involvement of the THP interviewers also ensured that data were not contaminated by misunderstandings arising from the participants' emic practices.

The role of the THP interviewers became profoundly important during the development of the glossary for the report. As a team, they had to identify all the THP terms that were used in the IDIs and communicate them to the researchers under the supervision of the THP experts. This enriched the data 
and also ensured that authentic meaning and explanations were assigned to the gathered data during analysis. For instance, during the data collection, there was a constant mention of the term "dipitsa" [we give them dipitsa]. In one of South African official language, Sepedi spoken by a sector of indigenous black population, this word directly translates to "cooking pots". As black non-THP researcher who speaks Sepedi, without the assistance of the THP-interviewers, I would have simply directly translated this to meaning cooking pots, thus lose out on the meaning indicating a certain THP medicine. The THP interviewers understood this and their knowledge became useful during the compilation of the glossary list. It was further important during this stage to authenticate the emic information shared between THP interviews and the participants as data. The richness of the study was highlight be the data transcripts that were individually thematically coded and discussed by the research team because this ensured that the information shared was not only unique but trustworthy as it was supported in other contexts, for instance data from one research site to the other. 


\section{CONCLUSIONS}

In this study, the THP interviewers highlighted blind spots that that can happen during a top-down academically oriented research where important information might be overlooked during data generation and collection. The participants in this research freely used THP terminology because they knew that the THP interviewers were familiar with the terminology, content knowledge and practices being discussed; this produced rich data for analysis.

During data collection, the non-THPs were involved in a cross-cultural study that involved learning through a phenomenological study and directly observing generation and collection of data by the recruited THP interviewers without their interferences as researchers. Non-THPs had to distance themselves and check whether the agreed-upon protocol was being followed. This methodological consideration is important for further research because it allows the temporary "sojourner" an opportunity to learn, observe and gather richer field notes. This, in turn, will enrich the data during analysis and, ultimately, affect the findings and recommendations arising from the study.

This study focused on a health matter, HIV and while it is challenging with its concepts, the THP interviewers could competently make follow up questions through probing on issues raised during the interviews. Probing might have been possible because HIV is a topic that is in social setting and people are exposed to information easily including questioning myths and misunderstanding from the participants. However, this might be a challenge in other settings, however in other topics where information is not readily available to foster a certain intellectual level of engagement it will be paramount to require assistants who are in the field, for instance in the law field making use of paralegal assistants; in dentistry using dental assistants; in psychology using honours students interested in the field of study and so forth. However, this paper concedes that this might not always be possible. It is thus important that training as indeed in this study, be undertaken with the entire research team so that the aim and objective of the study are clear to all involved in the study. 
Interviews in Cross-Cultural Research:

Working with the Custodians of

Traditional Health Practice as Researchers

in South Africa

\section{ACKNOWLEDGEMENTS}

PEPFAR, USAID

BroadReach Health Care 


\section{ÖZET}

Araştırmacılar araştırma yürütürken, kendi rollerinin ve sahip oldukları gücün daima farkında olmalıdırlar. Kültürlerarası araştırmada bu çok daha önemlidir çünkü en ufak bir hata büyük etik çıkarım ve sonuçlara yol açabilir. Kültürlerarası araştırma yürütürken, araştırmacı, araştırma alanından mümkün olduğunca özgün ve güvenilir veri sağlanmasından yükümlüdür. Aksi takdirde araştırma negatif bir bicimde etkilenecektir. Araştırmacının, araştırmanın her aşamasında esnek olması önemlidir. Araştırmanın esnekliği, araştırmacının belirtilen soruları kendine sorup cevaplamasıyla geliştirilebilir:

'Bu kültürlerarası çalışmayı olması gerektiği gibi mi yürütüyorum?'; 'Araştırma deseninden ötürü kültürlerarası olduğu için emik-etik yaklaşımı ve araştırma olgusu açısından neredeyim?'; 'Bunun gibi bir kültürlerarası çalışmada benim kişisel yanlılıklarım neler olabilir?'; ve 'Bu kültürlerarası çalışmada benim alg1lanan gücüm nedir?'

Bu sebeple, bu araştırmada da belirtildiği gibi, araştırmacının uygun yönlendirmeyi alması için, yerel bilginin uzman ve vasilerinden faydalanması yararlı olacaktır. Uzmanlar araştırmacının görevdeşleri ya da çalışılan kültür hakkında bilgisi olan toplumun üyeleri olabilir. 


\section{REFERENCES}

Alvesson, M., and Sköldberg, K. (2009). Reflexive Methodology: New Vistas for Qualitative Research (2nd ed.), London: Sage.

Al-Yateem, N. (2012). The Effect of Interview Recording on Quality of Data Obtained: A Methodological Reflection, Nurse Researcher, 19, No: 4, p.31-35.

Anyan, F. (2013). The Influence of Power Shifts in Data Collection and Analysis Stages: A Focus on Qualitative Research Interview, The Qualitative Report, 18, No:36, p.1. Retrieved from http://www.nova.edu/ssss/QR/QR18/anyan36.pdf.

Bogner, A., Littig, B., and Menz, W. (2009). Interviewing Experts, Hampshire: Palgrave Macmillan.

BroadReach Healthcare, Tabane, R., Mbele-Khama, S., and Dlamini, N. (2012). An Exploratory Study of How Traditional Health Practices (THP) in South Africa Communicate the Concepts of Disease Risk and Prevention to Their Patients. BroadReach Healthcare Report.

Chang, W. (2007). Cultural Competence of International Humanitarian Workers, Adult Education Quarterly. 57, No. 3, p.187-204.

Chenail, R. J. (2011). Interviewing the Investigator: Strategies for Addressing Instrumentation and Researcher Bias Concerns in Qualitative Research, The Qualitative Report, 16, No: 1, p.255262. Retrieved from http://www.nova.edu/ssss/QR/QR16-1/interviewing.pdf.

Doody, 0., Noonan, M. (2013). Preparing and Conducting Interviews to Collect Data, Nurse Researcher, 20, No: 5, p.28-32.

Frels, R. K., Onwuegbuzie, A. J. (2012). Interviewing the Interpretive Researcher: An Impressionist Tale, The Qualitative Report, 17(60), p.1-27. Retrieved from http://www.nova.edu/ssss/QR/QR17/frels.pdf.

Gubrium, J. F., Holstein, J. A. (Eds.) (2003). Handbook of Interview Research: Context \& Method, Thousand Oaks, CA: Sage.

Hesse-Biber, S. N., Leavy, P. L. (2007). Feminist Research Practice: A Primer. Thousand Oaks, CA: Sage.

Kvale, S., Brinkmann, S. (2008). Interviews: Learning the Craft of Qualitative Research Interviewing (2nd ed.), Thousand Oaks, CA: Sage. 
Kitzinger, C. (1991). Feminism, Psychology and the Paradox of Power. Feminism and Psychology. 1, No. 1, p. 111-129.

Mori, J. (2012). Tale of Two Tales: Locally Produced Accounts and Memberships During Research Interviews with a Multilingual Speaker, The Modern Language Journal, 96, No: 4, p. 489-506.

Mutua, K., Swadener, B.B. (Eds.) (2004). Decolonizing Research in Cross-Cultural Contexts: Critical Personal Narratives, Albany: State University of New York Press.

Rabionet, S. E. (2011). How I learned to Design and Conduct Semi-Structured Interviews: An Ongoing and Continuous Journey. The Qualitative Report, 16, No: 2, p.563-566. Retrieved from http://www.nova.edu/ssss/QR/QR16-2/rabionet.pdf.

Rubin, H. J., \& Rubin, I. S. (2006). Qualitative Interviewing: The Art of Hearing Data (2nd ed.), Thousand Oaks, CA: Sage.

Seidman, I. (2006). Interviewing as Qualitative Research: A Guide for Researchers in Education and the Social Sciences (3rd ed.), New York: Teachers College Press.

Triandis, H. C. (2000). Dialectics between Cultural and Cross-Cultural Psychology, Asian Journal of Social Psychology, 3, p.185-195.

Webster, J. P., John, T. A. (2010). Preserving a Space for Cross-Cultural Collaborations: An Account of Insider/Outsider Issues, Ethnography and Education, 5, No: 2, p.175-191.

Wilson, A. C. (2004). Reclaiming Our Humanity: Decolonizing and Recovery of Indigenous Knowledge, Mihesuah, D. \& Wilson, A. C. (Eds.), Indigenizing The Academy: Transforming Scholarship and Empowering Communities içinde (p.69-87). Lincoln: University of Nebraska Press.

Wilson, S. (2008). Research is Ceremony: Indigenous Research Methods. Halifax, UK: Fernwood.

Ǽgisdóttir, S, Gerstein, L. H. and Çinarbaş, D. C. (2008). Methodological Issues in Cross-Cultural Counseling Research: Equivalence, Bias and Translations, The Counseling Psychologist, 36, No: 2. p. 188-219. 